\title{
Uji Aktivitas Antibakteri Propionibacterium acnes Ekstrak Etanol dan Fraksi Daun Karuk (Piper sarmetosum Roxb. Ex. Hunter) serta Analisis KLT Bioautografi
}

\author{
Anisa Dwi Nuraeni ", Reza Abdul Kodir
}

Prodi Farmasi, Fakultas Matematika dan Ilmu Pengetahuan Alam, Universitas Islam Bandung, Indonesia.

" anisanuraeni82@yahoo.com, reza.abdul.kodir@gmail.com.

\begin{abstract}
Karuk (Piper sarmetosum Roxb. Ex. Hunter) is a plant that is considered to have antibacterial activity. Acne is a problem in the skin caused by the bacteria Propionibacterium acnes. This research's aimed to determine the potential antibacterial activity of ethanol extracts and karuk leaf's fractions, and can find out the class of chemical compounds contained from the ethanol extract and the fraction of karuk leaves which have antibacterial activity. Karuk leaf was extracted by maceration method using $96 \%$ ethanol solvent, followed by fractionation using the liquid-liquid extraction method with n-hexane, ethyl acetate, and water solvents. Antibacterial activity test of ethanol extract and fraction with a concentration of $2 \%$, $4 \%, 6 \%$, and $8 \%$ using the well diffusion agar method. To identify the class of compounds that have antibacterial activity, the TLC Bioautography method is used. From the results of research that has been done shows that ethanol extract and n-hexane fraction can inhibit the growth of Propionibacterium acnes with the highest inhibitory diameter of $10.11 \mathrm{~mm}$ in the extract, and in the n-hexane fraction of $10.93 \mathrm{~mm}$. in the ethyl acetate fraction and the water fraction there is no inhibitory zone formed so that it cannot provide antibacterial activity. The TLC Bioautography results did not show any inhibitory zones and there was no change in color when given a spotting viewer. So that compounds cannot be identified that have antibacterial activity
\end{abstract}

Keywords: Karuk leaf, Propionibacterium acnes, Bioautography TLC

Abstrak. Karuk (Piper sarmetosum Roxb. Ex. Hunter) merupakan tanaman yang diketahui memiliki aktivitas sebagai antibakteri. Jerawat merupakan permasalahan pada kulit disebabkan adanya bakteri Propionibacterium acnes. Penelitian ini bertujuan untuk menentukan potensi aktivitas antibakteri dari ekstrak etanol dan fraksi daun karuk, serta dapat mengetahui golongan senyawa kimia yang terkandung dari hasil ekstrak etanol dan fraksi daun karuk yang memiliki aktivitas antibakteri. Daun karuk diekstraksi dengan metode maserasi menggunakan pelarut etanol 96\%, dilanjutkan dengan fraksinasi menggunakan metode ekstraksi cair-cair dengan pelarut $\mathrm{n}$-heksan, etil asetat, dan air. Uji aktivitas antibakteri ekstrak etanol dan fraksi dengan konsentrasi $2 \%, 4 \%, 6 \%$, dan $8 \%$ menggunakan metode difusi sumuran agar. Untuk mengetahui golongan senyawa yang memiliki aktivitas sebagai antibakteri digunakan metode KLT Bioautografi. Dari hasil penelitian yang telah dilakukan menunjukan bahwa ekstrak etanol dan fraksi nheksan dapat menghambat pertumbuhan Propionibacterium acnes dengan diameter hambat tertinggi $10,11 \mathrm{~mm}$ pada ekstrak, dan pada fraksi n-heksan $10,93 \mathrm{~mm}$. pada fraksi etil asetat dan fraksi air tidak terbentuk adanya zona hambat sehingga tidak dapat memberikan aktivitas sebagai antibakteri. Hasil KLT Bioautografi tidak menunjukan adanya zona hambat serta tidak terdapat perubahan warna ketika diberikan penampak bercak. Sehingga tidak dapat teridentifikasi senyawa yang memiliki aktivitas antibakteri.

Kata Kunci: Daun karuk, Propionibacterium acnes, KLT Bioautografi 


\section{A. Pendahuluan}

Masa remaja merupakan masa dimana berlangsungnya proses perubahan dari anak-anak menjadi dewasa, perubahan tersebut dipengaruhi salah satunya karena hormonal. Ketidakseimbangan hormon di dalam tubuh dapat menyebabkan masalah pada kulit, masalah yang banyak terjadi pada remaja adalah munculnya jerawat. Jerawat merupakan suatu penyakit kulit akibat adanya peradangan kelenjar sebasea yang berkaitan dengan folikel rambut atau disebut juga pilosebasea. Jerawat dapat terjadi pada umur sekitar 14 - 17 tahun pada wanita, 16 - 19 tahun pada pria yang ditandai dengan adanya komedo, papul, pustul dan nodul (Djuanda,1999:232).

Faktor penyebab terjadinya jerawat diantaranya faktor genetik, hormonal, atau adanya infeksi bakteri. Bakteri penyebab jerawat diantaranya bakteri Propionibacterium acnes dan Staphylococcus epidermidis.

Pengobatan untuk jerawat diperlukan waktu yang lama sehingga penggunaan obat kimia dalam jangka waktu lama dapat menimbulkan efek samping seperti iritasi kulit, resistensi terhadap antibiotik, serta dapat menimbulkan kerusakan organ (Swanson,2003:359). Maka untuk mengurangi efek samping dari penggunaan obat kimia perlu dikembangkan pengobatan alternatif menggunakan tumbuhan herbal yang memiliki aktivitas sebagai anti bakteri. Salah satu tanaman yang berfungsi sebagai anti bakteri adalah Piper sarmetosum atau yang lebih dikenal sebagai karuk.

Penelitian ini bertujuan untuk menentukan adanya aktivitas antibakteri dari ekstrak etanol dan fraksi daun karuk terhadap Propionibacterium acnes. Dapat mengetahui golongan senyawa kimia yang terkandung dari hasil fraksi ekstrak daun karuk yang memiliki aktivitas antibakteri dengan menggunakan KLT bioautografi.

\section{B. Landasan Teori}

Piper sarmetosum Roxb. Ex. Hunter merupakan tanaman herba dari suku piperaceae yang tersebar luas diseluruh selatan Asia timur (Taweechaisupapong,2010:224).

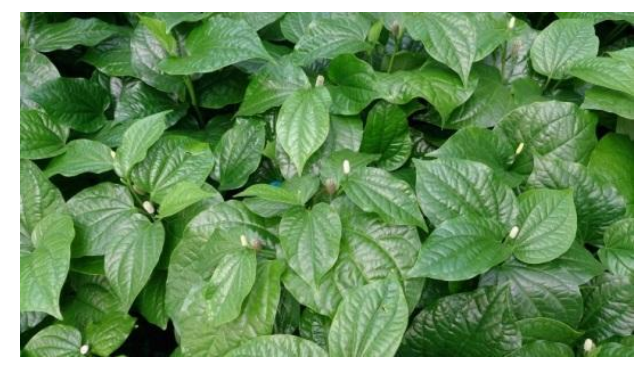

Gambar 1.1 Piper sarmetosum Roxb. Ex. Hunter

Klasifikasi tanaman karuk (Piper sarmetosum Roxb. Ex. Hunter) sebagai berikut:

Divisi : Magnoliophyta

Kelas : Magnoliopsida

Anak kelas : Magnoliidae

Bangsa : Piperales

Suku : Piperaceae

Marga : Piper

Jenis : Piper sarmetosum Roxb. Ex. Hunter.

Chavia sarmentosa Roxb. Ex Hunter

Nama lain : Karuk atau seserehan (Sunda), cabean (Jawa), kado - kado, sirih tanah (Maluku), amelun une (Ambon), gafu (Ternate)

(Hutapea,J.R,1994:215;Cronquist,1981:105; Syamul, 2005:178).

Di dalam tanaman karuk mengandung saponin, polifenol, flavonoid dan minyak atsiri. Kandungan karuk lainnya yaitu kalsium, kalium, magnesium, karoten, niasin, vitamin B1, B2 dan C serta dikenal sebagai antioksidan alami (Syamsul, 2005:178). 
Propionibacterium acnes merupakan kelompok bakteri gram positif yang memiliki bentuk seperti batang pleomorfik yang dapat memfermentasi gula untuk menghasilkan asam propionat, termasuk kedalam organisme anaerobik. Pertumbuhan bakteri Propionibacterium acnes membutuhkan waktu 7 hari pada suhu $35-37^{\circ} \mathrm{C}$ (Jappe, 2003:242).

Pembentukan jerawat diawali dengan penyumbatan pada kelenjar pilosebasea. Dalam jerawat saluran kelenjar melebar menyebabkan sebum bercampur dengan sel-sel kulit mati yang berlebih sehingga dapat membentuk sumbatan keratin. Sebum yang terakumulasi dapat menjadi sumber nutrisi bagi pertumbuhan Propionibacterium acnes sehingga memicu terjadinya inflamasi (Dipiro, 2008:1529).

Metode bioautografi merupakan metode sederhana yang digunakan untuk menunjukkan adanya aktivitas antibakteri atau antijamur. Metode ini menggunakan teknik kromatografi lapis tipis dengan respon mikroorganisme yang diuji berdasarkan aktivitas biologi dari suatu zat yang diuji berupa bakteri, jamur dan protozoa. Bioautografi dapat digunakan untuk mencari senyawa antibakteri atau antijamur yang terkandung dalam suatu sampel tumbuhan (Choma,2011:2684).

Keuntungan metode bioautografi mudah dilakukan, cepat, dapat digunakan untuk mengevaluasi senyawa dalam bentuk ekstrak yang masih kompleks.

\section{Metodologi Penelitian}

Penelitian mengenai uji aktivitas antibakteri Propionibacterium acnes ekstrak etanol dan fraksi daun karuk dilakukan di Laboratorium Riset Universitas Islam Bandung. Pada tahap pertama pengumpulan bahan dan determinasi tanaman. Bahan baku yang digunakan yaitu daun karuk yang diperoleh dari daerah Cariu, Cianjur, Jawa Barat. Kemudian dilakukan determinasi tanaman di herbarium Bandungese sekolah ilmu dan teknologi hayati, Institut Teknologi Bandung (SITH, ITB)

Tahap kedua dilakukan pembuatan simplisia. Tahap ketiga dilakukan pembuatan ekstrak etanol daun karuk dengan metode maserasi, pelarut yang digunakan yaitu etanol $96 \%$. Tahap keempat adalah fraksinasi terhadap ekstrak kental etanol $96 \%$ dengan metode ECC menggunakan pelarut $\mathrm{n}$-heksan,etil asetat, air. Tahap kelima dilakukkan pengujian aktivitas antibakteri. kemudian fraksinat dengan zona hambat paling tinggi dilakukan pemantauan KLT. Untuk mendeteksi senyawa aktif yang mempunyai aktivitas sebagai antibakteri dilakukkan dengan metode bioautografi.

\section{Hasil Penelitian dan Pembahasan}

Daun karuk segar sebanyak 3,5 kg dilkakukan determinasi. Tujuan dilakuannya determinasi yaitu untuk memastikan kebenaran bahan yang digunakan dalam penelitian. Hasil determinasi menunjukan bahan yang digunakan benar merupakan tanaman dari suku piperaceae dengan jenis Piper sarmentosa Roxb ex Hunter, dengan nama umum karuk atau cabean.

Ekstraksi dilakukan dengan cara dingin berdasarkan kandungan senyawa dalam bahan yang mengandung minyak atsiri sehingga untuk menjaga senyawa yang mudah menguap tidak rusak maka dipilih metode maserasi, prinsip dari maserasi yaitu perendaman simplisia dengan pelarut dapat menyebabkan terjadinya pemecahan dinding sel akibat adanya perbedaan tekanan antara di dalam dan luar sel, sehingga senyawa metabolit sekunder di dalam simplisa akan terlarut dengan pelarutnya (Yulianti,2016:7). Pelarut yang digunakan yaitu etanol 96\% karena dapat menarik senyawa polar maupun non polar Rendemen ekstrak yang diperoleh yaitu $22,394 \%$.

Fraksinasi dilakukan dengan metode ekstraksi cair- cair dengan tujuan untuk memisahkan senyawa berdasarkan tingkat kepolarannya. Pelarut yang digunakan n-heksan untuk melarutkan senyawa non polar, etil asetat untuk melarutkan senyawa semi polar, air untuk senyawa polar. Prinsip dari fraksinasi yaitu penarikan senyawa dengan menggunakan pelarut yang tidak bercampur, pada fraksinasi dilakukan proses penggojogan searah dan konstan untuk memaksimalkan penarikan senyawa.

Penapisan fitokimia merupakan suatu cara evaluasi untuk mendeteksi senyawa kimia yang terkandung di dalam tanaman. Golongan senyawa ini merupakan kelompok metabolit 
sekunder yang dapat memberikan efek farmakologi (Dash, 2016:38).

Tabel 1. Hasil Penapisan Fitokimia Simplisia dan Ekstrak Daun Karuk

\begin{tabular}{|c|c|c|}
\hline Golongan Senyawa & Simplisia & Ekstrak \\
\hline Alkaloid & + & + \\
\hline Flavonoid & + & + \\
\hline Tanin & - & - \\
\hline Kuinon & + & + \\
\hline Saponin & + & + \\
\hline Polifenolat & + & + \\
\hline Steroid/Triterpenoid & + & + \\
\hline Monoterpen/ Sesquiterpen & + & + \\
\hline
\end{tabular}

Keterangan: $(+)=$ Terdeteksi $(-)=$ Tidak Terdeteksi

Hasil yang diperoleh dari penapisan fitokimia pada simplisia dan ekstrak terdapat senyawa alkaloid, flavonoid, kuinon, saponin, polifenolat, steroid dan monoterpenoid. Senyawa tanin tidak terdeteksi kemungkinan terjadi akibat dipengaruhi oleh $\mathrm{pH}$ tanah, karena $\mathrm{pH}$ tanah yang rendah atau asam dapat mengurangi produksi tanin oleh tanaman (Ridha,2014:17).

Simplisia dan ekstrak selanjutnya dilakukan penetapan parameter standar yang terbagi menjadi dua parameter, yaitu parameter standar spesifik dan parameter standar non spesifik. Penetapan parameter standar ini bertujuan untuk menjamin keseragaman mutu simplisia dan keamanan bahan dalam memberikan efek farmakologi (Patel,2011:1152).

Tabel 2. Penetapan parameter standar

\begin{tabular}{|c|c|c|}
\hline No & Pengujian & Hasil Pengujian \\
\hline \multirow{2}{*}{1} & \multirow{2}{*}{ Organoleptik } & simplisia: berbentuk rajangan, hijau tua, berbau aromatik \\
\hline & & ekstrak: kental, berwarna hitam pekat, berbau aromatik \\
\hline 2 & Kadar Sari Larut Air & $20,64 \%$ \\
\hline 3 & Kadar Sari Larut Etanol & $20,00 \%$ \\
\hline 4 & Susut Pengeringan & $11,75 \%$ \\
\hline 5 & Kadar Abu Total & $12,13 \%$ \\
\hline 6 & Kadar Abu Tidak Larut Asam & $1,54 \%$ \\
\hline 7 & Kadar Air & $8,50 \%$ \\
\hline 8 & Bobot Jenis & 1,046 \\
\hline
\end{tabular}

Pemeriksaan organoleptis merupakan tahapan yang bertujuan untuk mengenali simplisia dan ekstrak dengan menggunakan panca indera (Yuri,2017:35).

Penetapan kadar sari larut air dan larut etanol bertujuan untuk mengetahui kandungan senyawa awal yang terlarut dengan perbedaan polaritas pelarut, pelarut yang digunakan yaitu campuran antara aquadest dengan kloroform, kegunaan kloroform yaitu untuk mencegah tumbuhnya mikroba pada saat bahan di maserasi (Rizka,2018:81). Hasil yang diperoleh rata rata pada kadar sari larut air yaitu 20,64\% sedangkan kadar sari larut etanol 20,00\%, hal tersebut menandakan bahwa kemampuan senyawa melarut di dalam air lebih tinggi dibandingkan pada etanol.

Hasil pengujian susut pengeringan yang diperoleh yaitu 11,754\%. Hasil susut pengeringan lebih besar dibandingkan dengan kadar air karena pada susut pengeringan terdapat senyawa lain yang mudah menguap selain air.

Kadar abu merupakan zat anorganik sisa hasil pembakaran, kadar abu berhubungan dengan kemurnian suatu bahan, kandungan mineral dan keamanan bahan. Pengukuran kadar abu bertujuan untuk mengetahui kandungan mineral internal dan eksternal (Sandjaja,2009:107). Nilai abu total yang diperoleh yaitu $12,132 \%$. Tingginya kadar abu total menunjukan semakin tinggi kandungan mineral di dalam nya. Kadar abu tidak larut asam menggambarkan terdapatnya kandungan logam yang tidak larut asam, adanya kontaminasi mineral. Nilai kadar 
abu tidak larut asam yaitu 1,543\% hasil tersebut cukup besar, pada (Kemenkes RI,2010:107) mengatakan abu tidak larut asam tidak lebih dari 1,1\%, kemungkinan karena faktor lingkungan, pada bahan terdapat tanah, kerikil yang masih menempel sehingga mempengaruhi hasil pengujian.

Parameter standar ekstrak dilakukan pengujian bobot jenis. Penetapan bobot jenis dilakukan untuk menentukan kerapatan ekstrak sehingga memberikan batasan ukuran massa per satuan volume, bobot berhubungan kemurnian dan ekstrak (Sholihah,2018:17). Pengujian bobot jenis menggunakan piknometer dengan melarutkan ekstrak, hasil bobot jenis ekstrak yang diperoleh sebesar 1,045.

Pengujian aktivitas antibakteri dilakukan dengan difusi agar metode sumuran karena dapat menampung konsentrasi lebih tinggi dibandingkan metode cakram sehingga lebih cepat berdifusi pada media Uji aktivitas antibakteri terhadap Propionibacterium acnes dilakukan menggunakan 4 larutan uji meliputi, ekstrak etanol daun karuk, fraksi n-heksan, fraksi etil asetat dan fraksi air dengan konsentrasi $2 \%, 4 \%, 6 \%, 8 \%$, Sebagai kontol negatif digunakan etanol 96\%, klindamisin digunakan sebagai kontrol positif.

Tabel 3. Hasil uji aktivitas antibakteri

\begin{tabular}{|c|c|c|c|c|c|c|}
\hline \multirow[b]{2}{*}{ Larutan üi } & \multicolumn{6}{|c|}{ Diameter hambat(nm) } \\
\hline & $2 \%$ & $4 \%$ & $6 \%$ & $8 \%$ & $\begin{array}{c}\text { K.posiif } \\
\text { Kimdamisin 0,01\% }\end{array}$ & $\begin{array}{l}\text { K. Negatif } \\
\text { Etand } 96 \% \%\end{array}$ \\
\hline Elstrak etanol & - & $632 \pm 4,75$ & $9,54 \pm 0,51$ & $10,11 \pm 0,66$ & $23,32 \pm 2,12$ & - \\
\hline Frakssin-keksan & $10,32 \pm 0,44$ & $7,08 \pm 5,35$ & $10,71 \pm 0,63$ & $10,93 \pm 0,58$ & $20,25 \pm 5,50$ & - \\
\hline Fraksi etil asetat & - & - & - & - & $24,79 \pm 1,77$ & - \\
\hline Fraksiair & - & - & - & - & $23,08 \pm 0,67$ & - \\
\hline
\end{tabular}

Berdasarkan hasil uji aktivitas pada fraksi n-heksan menunjukan zona hambat yang terbentuk lebih baik dibandingkan pada ekstrak etanol, karena pada ekstrak etanol senyawa yang terbentuk masih dalam gabungan senyawa, maka daya difusi dari ekstrak akan lambat karena gabungan senyawa tersebut dapat menutupi atau menghalangi aktivitas antibakteri. Sedangkan pada fraksi n-heksan kandungan senyawa yang dihasilkan dalam bentuk campuran senyawa yang lebih sederhana dengan sifat non polar, seperti golongan monoterpen, alkaloid. Efek yang dihasilkan dari adanya pemisahan senyawa berdasarkan perbedaan kepolaran memiliki hasil yang lebih baik dibandingkan dengan efek komplementer pada ekstrak (Yulianti,2016:7).

Menurut Davis (1971) termasuk kategori sedang apabila diameter yang dihasilkan 5-10 mm, maka uji aktivitas dari ekstrak dan fraksi n-heksan memiliki kategori sedang, dengan diameter zona hambat tertinggi pada konsentrasi $8 \%$ pada sampel ekstrak etanol dengan diameter 10,11 mm dan 10,93 pada fraksi n-heksan,

Pada fraksi etil asetat dan fraksi air tidak terlihat adanya zona hambat, hal tersebut terjadi karena kurang mampu nya sampel berdifusi dengan baik pada media. Karena senyawa yang tertarik pada pelarut etil asetat dan air lebih kecil sehingga tidak dapat mengambat pertumbuhan Propionibacterium acnes (Isti,2018:105).

Fraksi n-heksan dipilih untuk dilakukan analisis senyawa antibakteri dengan metode kromatografi lapis tipis bioautografi. Fase gerak yang digunakan untuk fraksi n-heksan yaitu kloroform:etil asetat (2:1), Hasil KLT diamati dibawah lampu UV 366, spot pertama teramati pada Rf 0,27, spot kedua dengan nilai Rf 0,68.
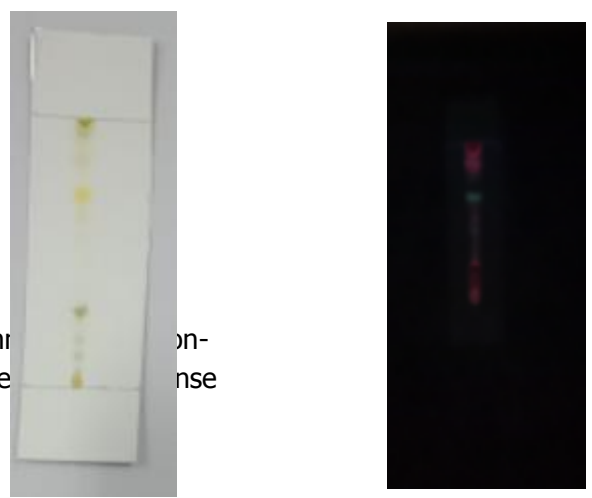
Gambar 1. pemantauan KLT fraksi n-heksan dengan fase diam silica gel GF254 dan fase gerak kloroform: etil asetat (2:1). (a) pengamatan dibawah sinar tampak, (b) pengamatan dibawah lampu uv $366 \mathrm{~nm}$.

Pada metode bioautografi, senyawa antibakteri dari plat KLT akan berdifusi ke dalam media TSA yang telah berisi suspensi bakteri Propionibacterium acnes dan menghasilkan zona hambat. Pada fraksi n-heksan zona hambat pada media agar tidak terbentuk zona bening disekitar media yang telah ditempelkan plat KLT hasil elusi fraksi n-heksan, hal tersebut dapat terjadi karena konsentrasi senyawa yang terdapat pada plat KLT terlalu rendah sehingga tidak mampu menghambat pertumbuhan bakteri (Mukhriani,2017:30). Hasil penelitian setelah disemprotkan penampak bercak pada plat KLT yang telah di totolkan fraksi n-heksan tidak terjadi perubahan warna, hal tersebut terjadi karena pereaksi yang digunakan sudah rusak karena penyimpanan yang terlalu lama.

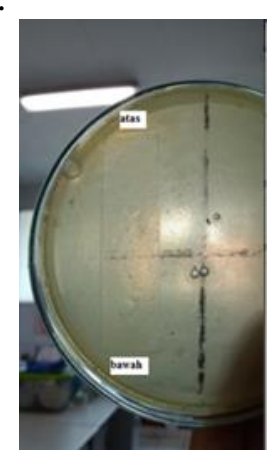

Gambar 2. pengamatan KLT bioautografi

\section{Kesimpulan}

Berdasarkan penelitian yang telah dilakukan dapat disimpulkan pada ekstrak etanol dan fraksi n-heksan memiliki respon hambatan lemah terhadap aktivitas Propionibacterium acnes. Pada konsentrasi 8\% dari ekstrak memberikan hasil diameter 10,11mm, dan pada fraksi n-heksan $10,93 \mathrm{~mm}$. Pada pengujian KLT bioautografi hasil yang diperoleh tidak terbentuk zona bening serta tidak terdapat perubahan warna ketika diberikan penampak bercak. Sehingga belum teridentifikasi senyawa yang memiliki aktivitas antibakteri.

\section{E. Saran}

Disarankan untuk melakukan pengujian KLT biautografi lainya disertai dengan penampak bercak yang lebih spesifik. Disarankan pula melanjutkan penelitian ke tahap isolasi untuk mengetahui senyawa yang berperan.

\section{Daftar Pustaka}

[1] Choma. Irena M., Edyta M. Grzelak. (2011). Bioautography detection in thin layer chromatography. Journal of chromatography A, 1218. Poland.

[2] Cronquist, A.,(1981). An Integrated System of Classification of Flowering Plants, Columbia University Press, New York.

[3] Dash, Pritesh Ranjan. (2016). Phytochemical screening and pharmacological investigations 
on Hedychium coronarium, Hamburg, Anchor Academic Publising

[4] Davis, W.W dan T. R Stout. (1971). Disc plate method of microbiological antibiotic assay. Applied microbiology.

[5] Dipiro. J.T. (2008). Pharmacoteraphy Handbook 7 th edition, Mc Graw Hill, New York.

[6] Djuanda,A. Hamzah, M dan Aisah, S. (2009). Ilmu Penyakit Kulit dan Kelamin. Fakultas Kedokteran Universitas Indonesia, Jakarta.

[7] Hutapea, J.R. dkk. (1994). Inventaris Tanaman Obat Indonesia (III), Depkes RI,Jakarta.

[8] Indah Solihah et all, (2018). Standardization of ethanol extract of Tahongai leaves (Kleinhovia hospita L). Science \& technology Indonesia 14-18.

[9] Kementrian kesehatan RI. (2010). Suplemen I farmakope herbal indonesia. Jakarta. Direktorat jendral bina kefarmasian dan alat kesehatan

[10] Mukhriani, dkk. (2017). Uji aktivitas antibakteri fraksi etil asetat korteks kayu jati (Tectona grandis L.F) terhadap beberapa bakteri uji. Jurnal kesehatan fakultas ilmu kesehatan Universitas Islam Alaudin Makasar. Vol 5 no 1.

[11] Patel Parthik, et al. (2011). WHO Guidlines On Quality Control of Herbal Medicines. International Journal of Research in Ayurveda\&Pharmacy, 2(4).

[12] Rizka F Lestari, (2018). Penetapan parameter standar simplisia dan ekstrak etanol daun kratom (Miragyna speciosa Korth) yang tumbuh di kabupaten Kapuas Hulu dan kabupaten Melawi.

[13] Sandjaja, Atmarita, (2009). Kamus gizi pelengkap kesehatan keluarga. Jakarta. Penerbit kompas.

[14] Swanson, I.K. (2003), Antibiotik Resistance of Propionibacterium acnes in Acne vulgari. Dermatol Nurs, 15 (4).

[15] Syamsul Hidayat, rodame. M, Napitulu. (2005). Kitab tumbuhan obat, penebar swadaya grup, Jakarta.

[16] Uta Jappe. (2003). Pathological mechanism of acne with special emphasis on Propionibacterium acnes and related theraphy. Departement of dermatology university of Heidelberg, Germany. Acta derm venereol 83.

[17] Yulainti Lestari., dkk. (2016). Aktivitas antibakteri gram positif dan negatif dari ekstrak dan fraksi daun nipah (Nypa fruticans Wurmb.) asal pesisir sungai kakap Kalimantan Barat. Jurnal kesehatan kefarmasian volume 5 (4). Universitas Tanjungpura. 